\title{
Fatal accidents among Icelandic seamen: 1966-86
}

\author{
Vilhjálmur Rafnsson, Hólmfríour Gunnarsdóttir
}

\begin{abstract}
Objective-To investigate whether fatal accidents, including drownings, have decreased among Icelandic fishermen and seamen.

Design-Historical prospective study. The study population was record linked with the National Register and the Register of Deceased to get information on water transport accidents (ICD-7, E850-E858) during the period 1966-86. The number of persons in each calendar year and the number of days at sea registered at the pension fund were both used as denominator to find annual mortalities.

Setting-Iceland.

Subjects-27 884 seamen who were members of the Seamen's Pension Fund. The cohort included both fishermen and seamen from the merchant fleet.
\end{abstract}

Main outcome measures-Changes in mortality from all accidents and drownings from 1966-86.

Results-The mortality for all fatal accidents was $89 \cdot 4$ per $10^{5}$ person-years and did not change appreciably during the study period. The mortality for drowning was unchanged at 73.2 per $10^{5}$ person-years. The greatest number of drownings were among those 20-24 years of age but the mortality for drowning was highest among those 45-54 years of age.

Conclusion-Mortality because of fatal accidents and drownings among these seamen was high and did not conclusively decrease during the study period. Further preventive measures are needed.

In former times fatal accidents among seamen in Icelandic coastal waters were not only the concern of

Department of Preventive Medicine, University of Iceland, Sigtúni 1, 101 Reykjavík, Iceland

V Rafnsson

Department of Occupational Medicine, Administration of Occupational Safety and Health, Bíldshofda 16, 112 Reykjavík, Iceland

H Gunnarsdóttir, V Rafnsson
Icelanders. Many foreign fishermen have lost their lives while fishing the rich banks of Iceland. ${ }^{1}$

It has been maintained that the struggle for survival in Iceland in past centuries demanded the sacrifice of seamen's lives. These days, however, men no longer succumb to their fates without resistance and accident prevention has become increasingly successful. ${ }^{2}$ Safety at sea has long been the subject of widespread discussion in Iceland and numerous persons and organisations have been concerned with these matters: volunteer associations for accident prevention, the national government, and the seamen and fishing vessel owners themselves. In recent years a rescue helicopter has been in operation. The aim of this study was to find out whether fatal accidents, especially drownings, have decreased among Icelandic fishermen and other seamen.

Material and methods

Data from the Seamen's Pension Fund were used for this study. The fund was established in 1958 and computerised in 1965-6. At first it was only for the crews on trawlers. Trawlers were defined as fishing vessels of 500 tons or larger. From 1960 onwards seamen from the merchant fleet were included. Some of the officers and machinists were never members of the fund. Fishermen, both ordinary seamen and officers, on small fishing boats of a minimum size of 12 tons became members in 1970. Numbers of fund members did not increase substantially with the inclusion of the seamen on the merchant fleet from 1960. On the other hand the number of members doubled in 1970 when the fishermen on small fishing boats were included. The members of the fund increased each year from 1970-81, but decreased after that (fig 1). Fishermen have always made up most of the members of the fund, and the number of seamen on the merchant fleet is estimated to be about 1000 each year. The use of this material meant that it was not possible to separate fishermen from others; nor was there information on what duties individual members performed on board or the kind of ship that they served on. Roughly $70 \%$ of all Icelandic seamen are members of this pension fund.

Each member was registered with the fund according to his identification number; the total cohort comprised 27884 men. Record linkage was done with the National Register, the Register of Deceased, and the Register of Causes of Death, all of which are 


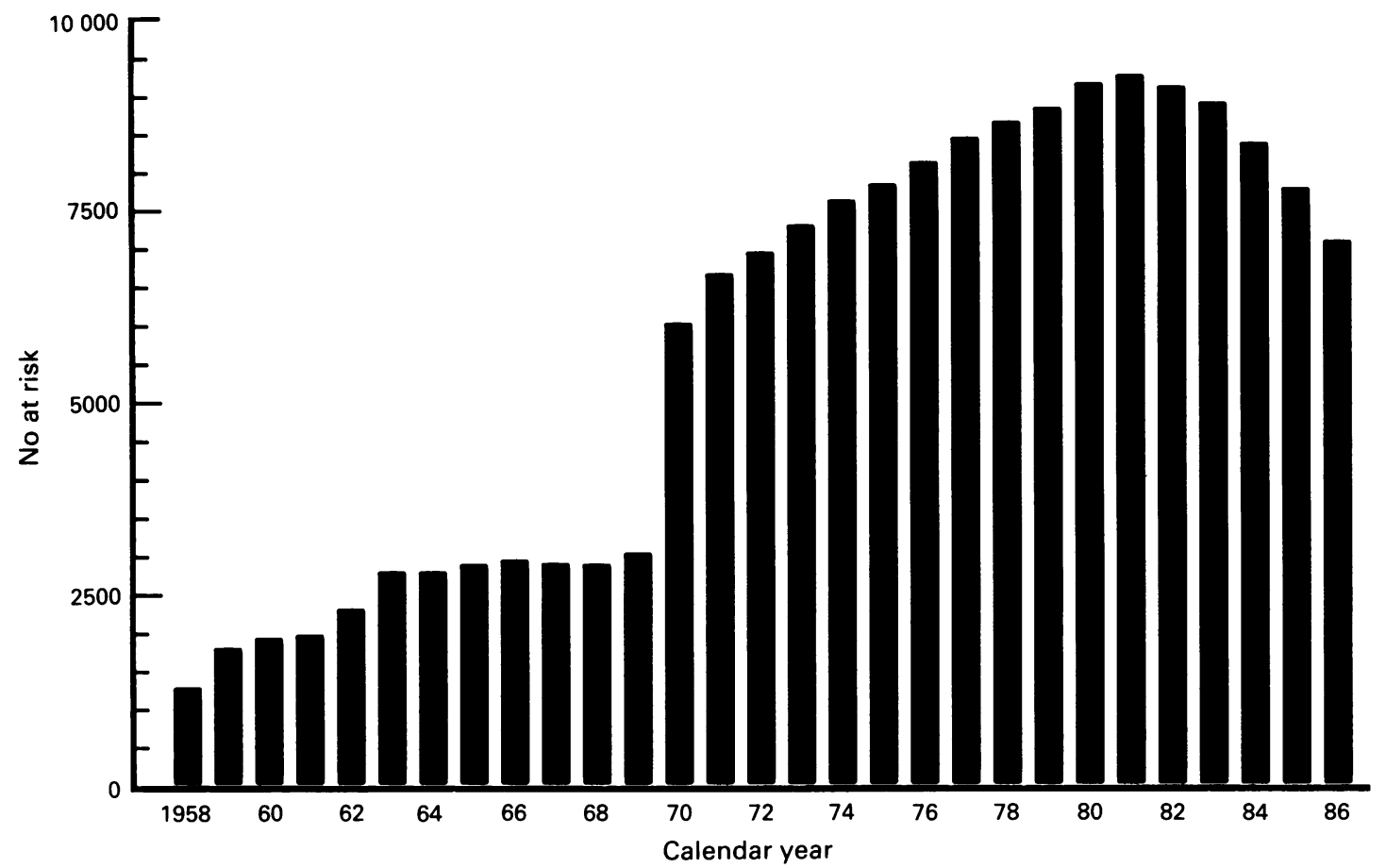

Figure 1 Number of members of the pension fund who were at risk each year.

kept at the Statistical Bureau of Iceland. The record linkage was permitted by the Data Inspection Committee. As the Register of Deceased and the Register of Causes of Death have been computerised since 1966 the follow up started that year and extended to 1986 , the last year information was obtained from the fund.

The causes of death obtained from death certificates were reclassified according to the seventh revision of the International Classification of Diseases (ICD-7), ${ }^{3}$ as different revisions had been in use during the study period. The seventh revision was chosen because the Cancer Register in Iceland uses it and it has been used in some former mortality and cancer incidence studies. ${ }^{45}$ The ICD-7 numbers for accidental deaths at sea are E850-E858, called water transport accidents. Drownings in water transport accidents have the numbers E850 and E851.

A fatal accident at sea was only included if it had occurred in a year when the man was a member of the fund. The numerator was calculated in this manner.

The number of person-years was estimated on the basis of the number of men registered each year without respect to the contributions paid for each man. Thus it did not take into account whether he had worked an entire year or only a part of it. In this way the denominator for calculation of mortality was calculated and presented as a rate per $10^{5}$ personyears.
The fund contains information on the number of days a year each man served at sea. These ranged from one to 365 . The mean value of days at sea for each year ranged from 157.7 to 183.8 . The number of work-years was calculated by dividing the total number of days at sea each year by 365 . In this way a new denominator was found for calculating the mortality-namely, per $10^{4}$ work-years. The time the members of the fund were at risk is thus taken into account in a manner that differs from the method of finding the person-years.

Mortalities were calculated for each year during the study period and for five-year age groups. Special attention was paid to the period after 1970 , as after that year no fundamental changes occurred in the membership of the fund. The $95 \%$ confidence intervals were calculated assuming a Poisson distribution. ${ }^{6}$ For the correlation between calendar year and mortality the Spearman's rank correlation coefficient was calculated as it does not depend on the distribution of the material. ${ }^{78}$

\section{Results}

Table 1 and fig 2 show the mortality for all fatal accidents per $10^{5}$ person-years. The rates during the first years, (before 1970) were highest, but the rate was lowest during the period 1977-81. The Spearman's rank coefficient between calendar year and 
Table 1 Fatal accidents among members of the pension fund classified according to intervals through 1966-86

\begin{tabular}{lcccc}
\hline $\begin{array}{l}\text { Time } \\
\text { period }\end{array}$ & $\begin{array}{l}\text { No of } \\
\text { cases }\end{array}$ & $\begin{array}{l}\text { Person- } \\
\text { years }\end{array}$ & $\begin{array}{l}\text { Mortality } \\
\text { per } 10^{5} \\
\text { person- } \\
\text { years }\end{array}$ & $(95 \%$ CI) \\
\hline $1966-71$ & 32 & 24422 & $131 \cdot 0$ & $(89 \cdot 6-185 \cdot 0)$ \\
$1972-76$ & 35 & 37784 & $92 \cdot 6$ & $(64 \cdot 5-128 \cdot 8)$ \\
$1977-81$ & 28 & 44296 & $63 \cdot 2$ & $(42 \cdot 0-91 \cdot 4)$ \\
$1982-86$ & 37 & 41.147 & $89 \cdot 9$ & $(63 \cdot 3-123 \cdot 9)$ \\
$1966-86$ & 132 & 147649 & $89 \cdot 4$ & $(73 \cdot 6-104 \cdot 6)$ \\
\hline
\end{tabular}

mortality rates for the period $1966-86$ was $-0 \cdot 159$, which shows that the mortality had decreased during the period although this is not statistically significant. The mortality rate for the entire period was 89.4 per $10^{5}$ person-years.

Drownings represent a portion of the fatal accidents at sea. Table 2 and fig 3 show mortality from drownings. This did not decrease appreciably during the study period; Spearman's rank coefficient was -0.094 . The annual mortality for the period was 73.2 per $10^{5}$ person-years.

Figure 4 shows the results of calculating the mortality for all fatal accidents using work-years. They are similar to those for person-years (fig 2). Here the Spearman's rank coefficient was $-0 \cdot 150$; the mortality decreased slightly with years, although this was not statistically significant.
Table 2 Drownings among members of the pension fund classified according to intervals through 1966-86

\begin{tabular}{lccll}
\hline Time & No of & $\begin{array}{l}\text { Mortality } \\
\text { per } 10^{5} \\
\text { perion- } \\
\text { years }\end{array}$ & $\begin{array}{l}\text { Nears } \\
\text { years }\end{array}$ & $\begin{array}{l}\text { years } \\
(95 \%)\end{array}$ \\
\hline $1966-71$ & 20 & 24422 & $81 \cdot 9$ & $(50 \cdot 0-126 \cdot 5)$ \\
$1972-76$ & 30 & 37784 & $79 \cdot 4$ & $(53 \cdot 6-113 \cdot 3)$ \\
$1977-81$ & 26 & 44296 & $58 \cdot 7$ & $(38 \cdot 3-86 \cdot 0)$ \\
$1982-86$ & 32 & 41147 & $77 \cdot 8$ & $(53 \cdot 2-109 \cdot 8)$ \\
$1966-86$ & 108 & 147649 & $73 \cdot 2$ & $(55 \cdot 1-82 \cdot 4)$ \\
\hline
\end{tabular}

Figure 5 shows the mortality from drownings per work-years. The results are again similar to those obtained when person-years were used (fig 3). The Spearman's rank coefficient was $-0 \cdot 120$.

When restricting the analysis to the period from 1970-86 the Spearman's rank coefficients between calendar years and mortality from all fatal accidents were $0 \cdot 104$ (person-years) and $0 \cdot 189$ (work-years). For drownings the coefficients were -0.028 (personyears) and $0 \cdot 100$ (work-years). None of these coefficients is statistically significant.

Table 3 and fig 6 shows the distribution of drownings by age-groups. The greatest number of drownings occurred among those 20-24 years of age. Figure 7 shows the rates in each age group per $10^{5}$ personyears. The highest rates were in the $45-49$ and 50-54 year age groups and then in the 30-34 year age group.

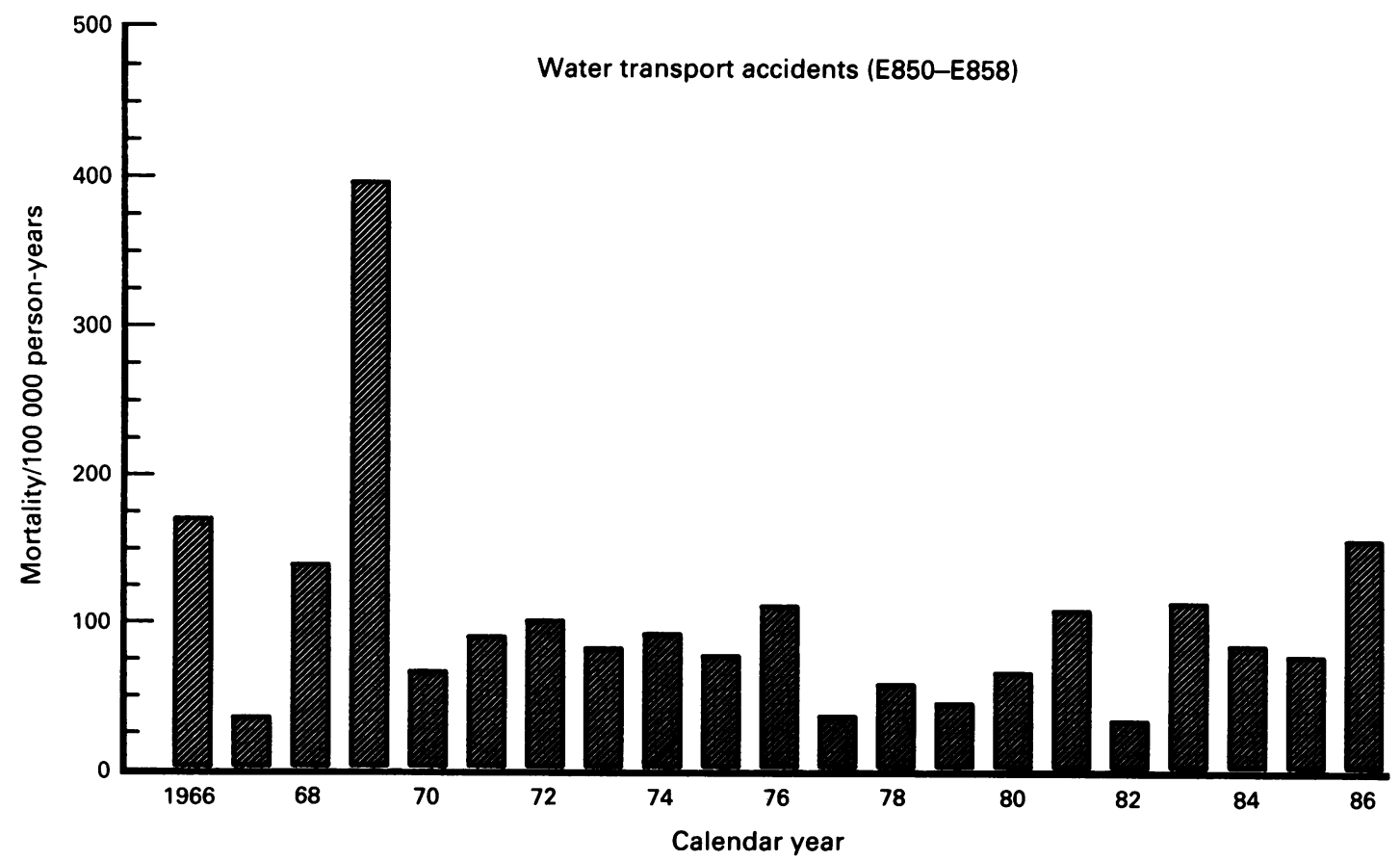

Figure 2 Mortality per $10^{5}$ person-years from water transport accidents (ICD-7, E850-E858) for each calendar year 1966-86. 


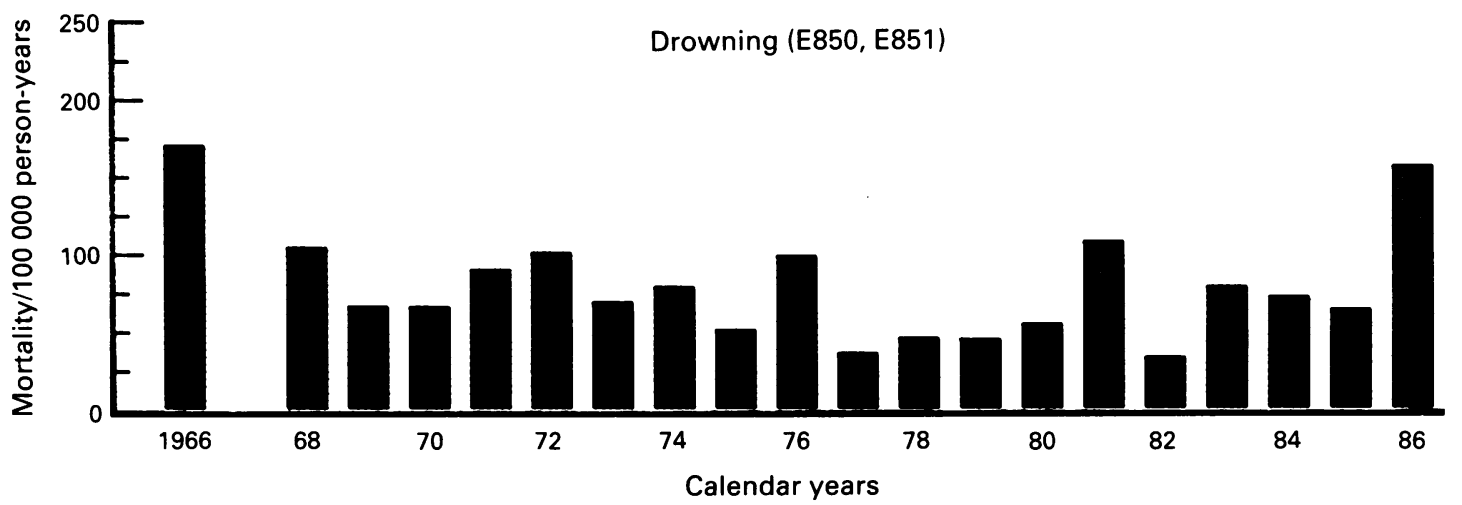

Figure 3 Mortality per $10^{5}$ person-years from drowning (ICD-7, E850, E851) for each calendar year $1966-86$.

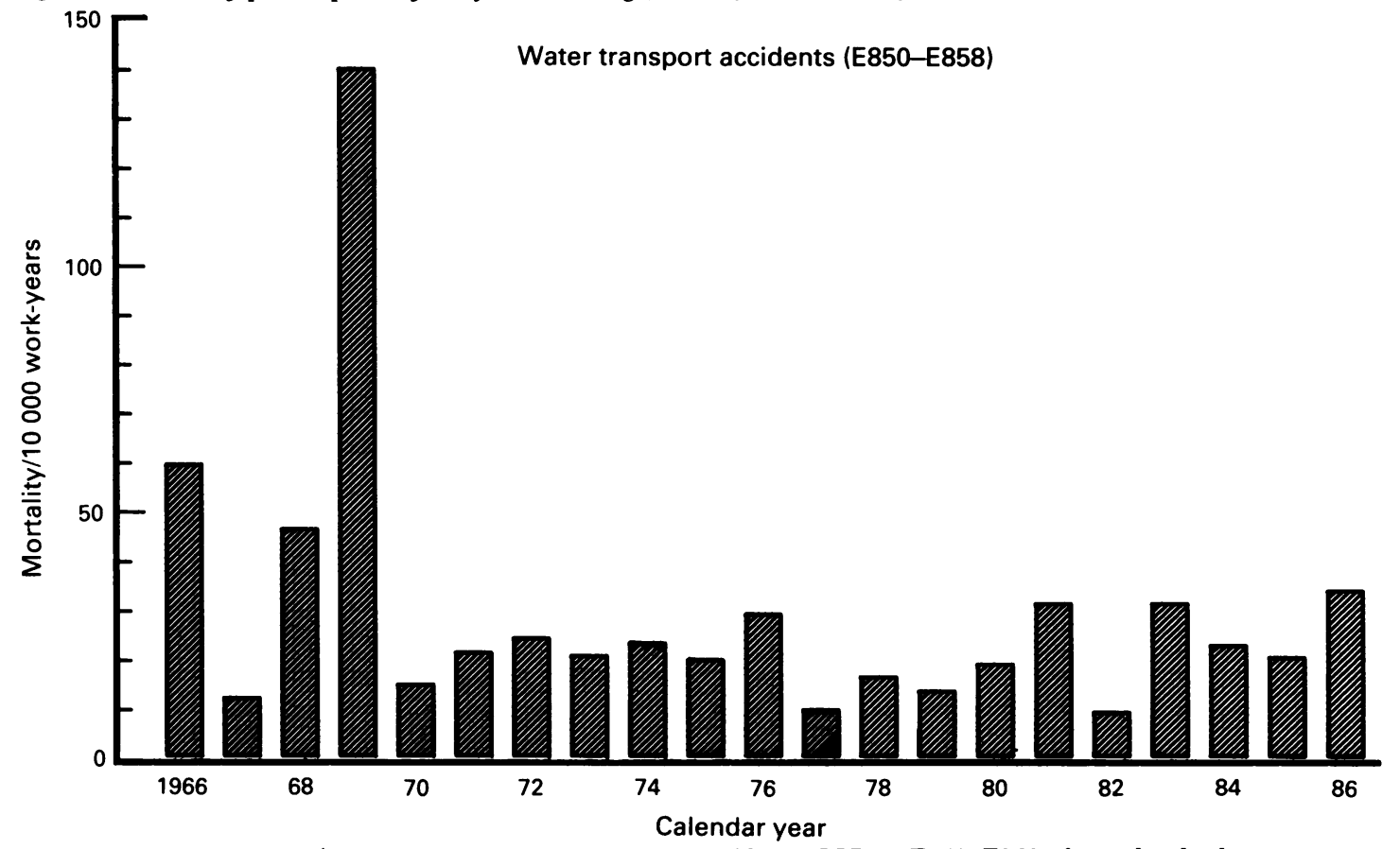

Figure 4 Mortality per $10^{4}$ work-years from water transport accidents (ICD-7, E850-E858) for each calendar year 1966-86.

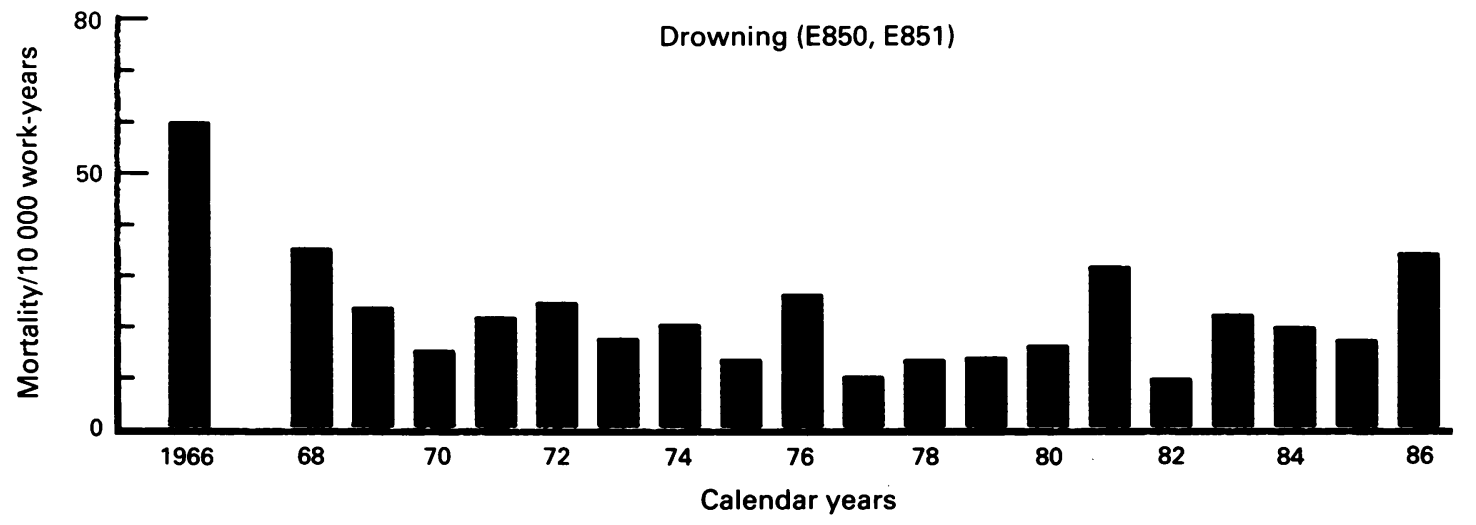

Figure 5 Mortality per 104 work-years from drowning (ICD-7, E850, E851) for each calendar year $1966-86$. 
Table 3 Drownings among members of the pension fund classified according to age

\begin{tabular}{lcccc}
\hline Age & No of & \multicolumn{4}{c}{$\begin{array}{l}\text { Merson- } \\
\text { Mer 10 } \\
\text { groups }\end{array}$} & $\begin{array}{l}\text { Nerson- } \\
\text { perses } \\
\text { years }\end{array}$ & $(95 \%$ CI $)$ \\
\hline$\leqslant 19$ & 9 & 22382 & $40 \cdot 2$ & $(18 \cdot 4-76 \cdot 3)$ \\
$20-24$ & 29 & 34925 & $83 \cdot 0$ & $(55 \cdot 6-119 \cdot 3)$ \\
$25-29$ & 15 & 25960 & $57 \cdot 8$ & $(32 \cdot 3-95 \cdot 3)$ \\
$30-34$ & 17 & 18239 & $98 \cdot 6$ & $(54 \cdot 3-149 \cdot 2)$ \\
$35-39$ & 10 & 13422 & $74 \cdot 5$ & $(35 \cdot 7-137 \cdot 0)$ \\
$40-44$ & 7 & 10837 & $64 \cdot 6$ & $(26 \cdot 0-133 \cdot 1)$ \\
$45-49$ & 9 & 8327 & $108 \cdot 1$ & $(49 \cdot 4-205 \cdot 2)$ \\
$50-54$ & 7 & 6059 & $115 \cdot 5$ & $(46 \cdot 4-238 \cdot 0)$ \\
$\geqslant 55$ & 5 & 7498 & $66 \cdot 7$ & $(21 \cdot 7-155 \cdot 6)$ \\
All & 108 & 147649 & $73 \cdot 2$ & $(55 \cdot 1-82 \cdot 4)$ \\
\hline
\end{tabular}

When the study was divided into two separate periods-namely, before or after the fishermen on small boats were included in the fund, and the difference in mortality analysed, it became clear that it was higher before 1970 than afterwards, and the difference was statistically significant for all fatal accidents.

\section{Discussion}

The results of this study show that fatal accidents among seamen, including drownings, have not decreased conclusively during the study period.
It is of interest to compare the situation in Iceland with that in neighbouring countries. A recent study among registered fishermen along the Atlantic coast of Canada showed that mortality because of accidents at sea was 45.8 per $10^{5}$ fishermen per year. ${ }^{9}$ Contrary to the results obtained in our study the mortality was highest among the younger age groups. The Canadian study covers the period 1975-83. The material in the present study differs somewhat from that used in the Canadian one, as it includes both fishermen and crews from the merchant fleet. In earlier studies, British fishermen had a higher mortality. Moore ${ }^{10}$ found that mortality was 180 per $10^{5}$ fishermen per year in 1969 and during the period 1948-64 the rates because of accidents were 26-247 per $10^{5}$ fishermen a year. ${ }^{11}$ Reilly $^{12}$ reported that during 1971-80 the annual mortality was 93 per $10^{5}$ fishermen a year.

Comparison of mortality for fatal accidents at sea with those from Denmark and Norway is not possible because unclearly defined "work-years" were used for calculating the rates. ${ }^{13-16}$ These studies indicate that fatal accidents at sea are about 36 to 50 times more frequent than occupational accidents ashore. Weihe ${ }^{13}$ estimated the mortality among fishermen in Denmark during $1982-85$ to be 156 per $10^{5}$ fishermen a year.

Attempts have been made to estimate the underrecording because of men lost at sea whose bodies

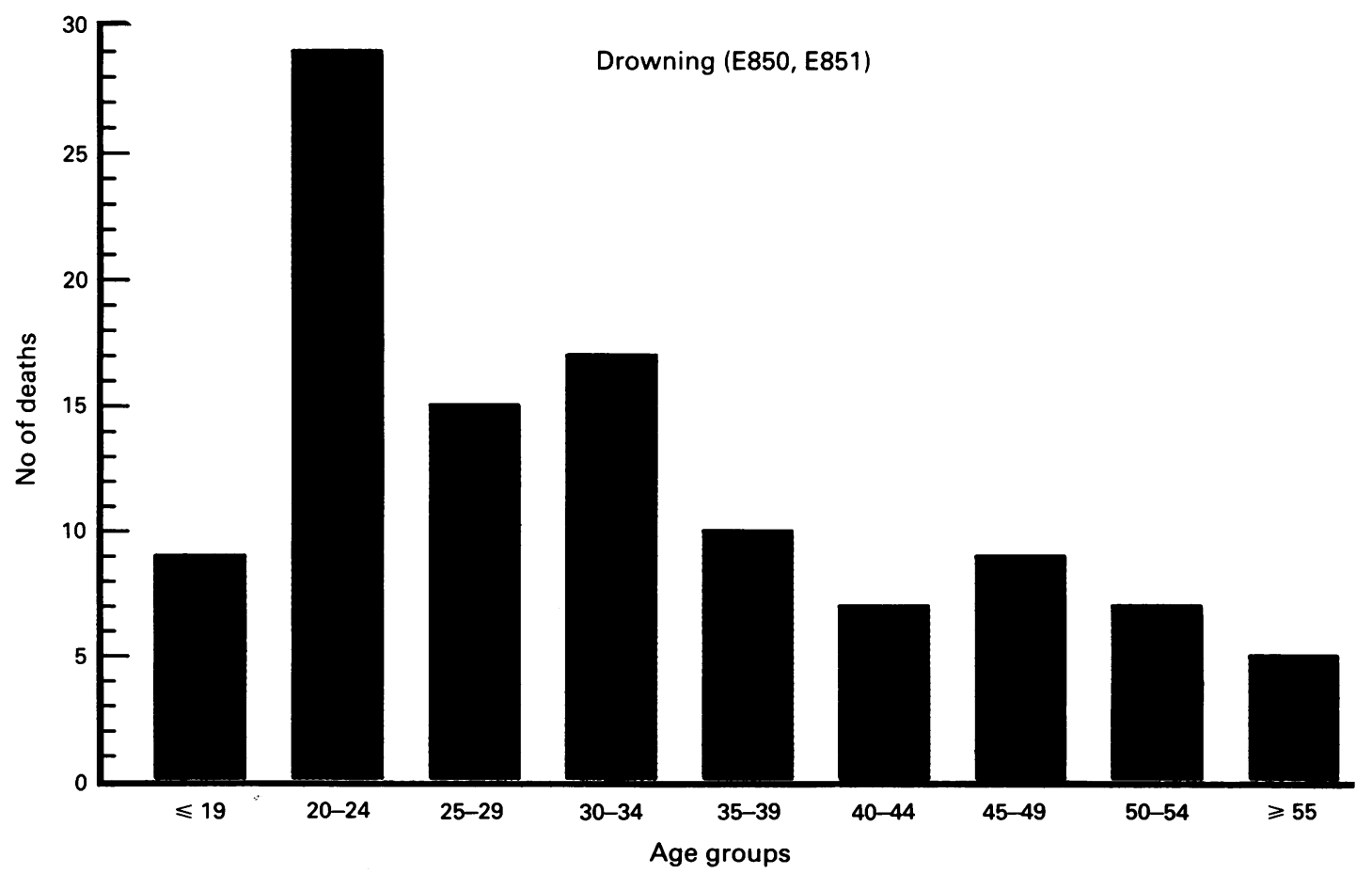

Figure 6 Number of deaths from drowning (ICD-7, E850, E851) classified according to age groups. 


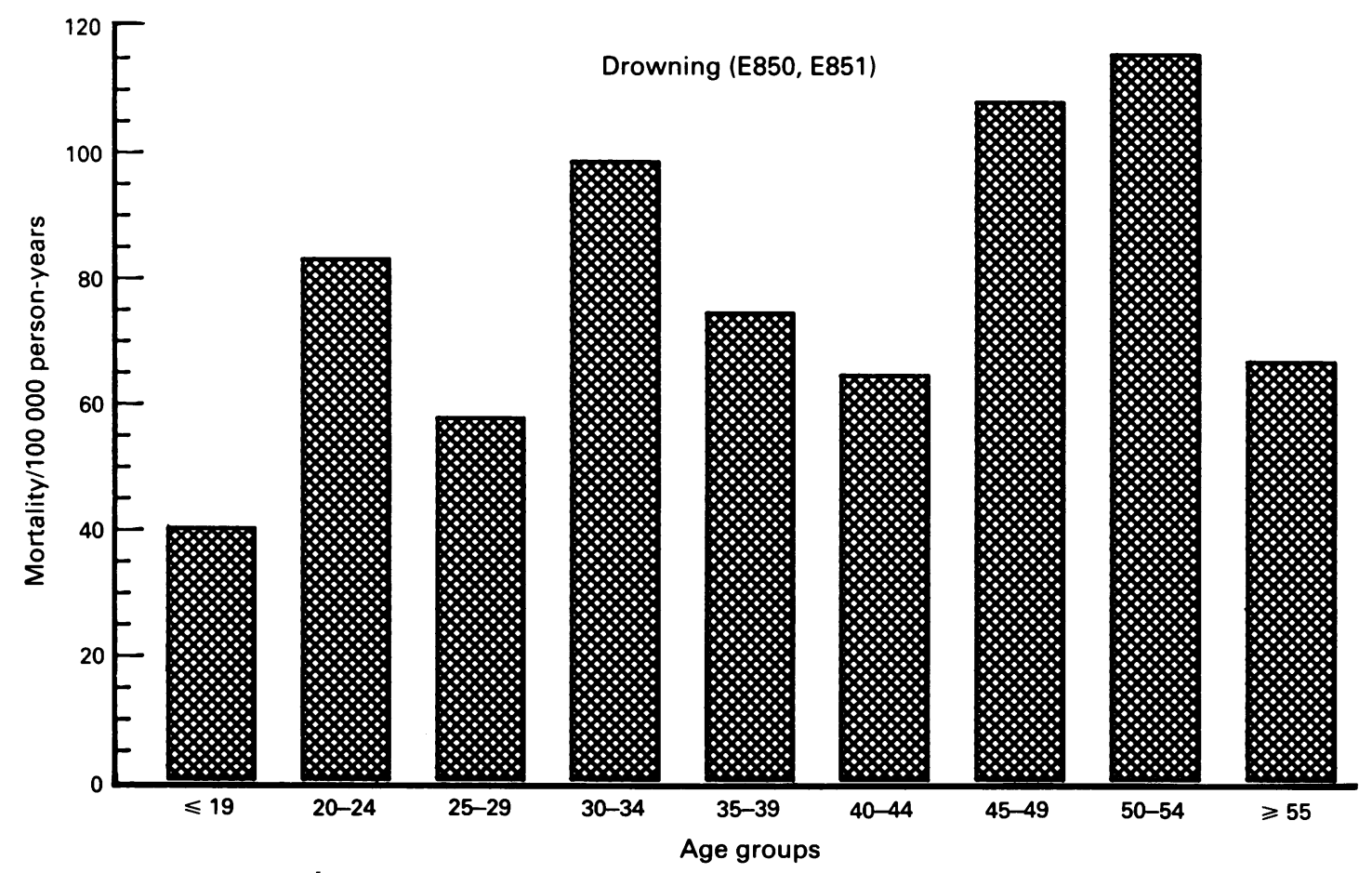

Figure 7 Mortality per $10^{5}$ person-years from drowning (ICD-7, E850, E851) classified according to age groups.

were never found. ${ }^{9-11}$ As a result, the cause of death may not be registered in the mortality files and can affect the mortality risk profoundly.

When person-years are used as a basis for calculation the time during which men are at risk of accident is estimated to be longer than it actually is. The denominator used to calculate the mortality is too high and the risk of fatal accident is in fact higher than the results indicate. The underestimation of the risk does not present a handicap for comparison between years as this applies equally to all calendar years. This can be seen as part-time jobs at sea are fairly evenly distributed through the years, a fact which becomes apparent as the results do not change appreciably when work-years are used for calculating the rates.

There were more fatal accidents at sea than these results indicate if we include all those who had paid to the pension fund at any time during the study period. Many deaths were excluded as these occurred after the end of the person's contributions to the fund.

We thus conclude that mortality because of fatal accidents and drownings among these seamen was high and did not decrease during the study period. The rates for drowning were highest among those 45-54 years of age, although the greatest number of drownings occurred in the $20-24$ year age group.

1 Pugh LGC. Isafjordur trawler disaster: Medical aspects. $\mathrm{Br}$ Med J 1968;I:826-9.
2 Finnbogadóttir V. Hvað er eitt lif án samhjälpar frá vinum? Ávarp á afmalisthingi SVFI 27. mai 1988. Arbók Slysavarnafélags Islands 1989. Reykjavik: Slysavarnafélag Islands 1989.

3 Steenland $\mathrm{K}$, Beaumont $\mathrm{J}$, Spaeth S, Brown D, Okun A, Jurcenko $\mathrm{L}$, et al. New developments in the life table analysis system of the National Institute for Occupational Safety and Health. J Occup Med 1990;32:1091-8.

4 Rafnsson V, Jóhannesdóttir SG, Oddsson H, Benediktsson H, Tulinius H, Magnússon G. Mortality and cancer incidence among marine engineers and machinists in Iceland. Scand $J$ Work Environ Health 1988;14:197-200.

5 Rafnsson V, Gunnarsdóttir H. Mortality study of fertiliser manufacturers in Iceland. Br J Ind Med 1990;47:721-5.

6 Ahlbom A. Biostatistik för epidemiologer. Lund: Studentlitteratur, 1990.

7 Siegel S. Nonparametric statistics for the behavioral sciences. International student edition. New York: McGraw-Hill, 1956.

8 Rafnsson V. Mortality from ischemic heart disease in Iceland, 1951-1985. Ann Epidemiol 1991;1:493-503.

9 Hasselback P, Neutel CI. Risk for commercial fishing deaths in Canadian Atlantic provinces. Br J Ind Med 1990;47:498-501.

10 Moore SRW. The mortality and morbidity of deep sea fishermen sailing from Grimsby in one year. Br J Ind Med 1969;26: $25-46$.

11 Schilling RSF. Trawler fishing: an extreme occupation. Proceedings of the Royal Society of Medicine 1966;59:405-10.

12 Reilley MSJ. Mortality from occupational accidents to United Kingdom fishermen 1961-80. Br J Ind Med 1985;42:806-14.

13 Weihe P. Söens folk-Arbejdsmiljöets helbredspåvirkning. In: Jepsen JR, Christensen JM, eds. Söfarts-og fiskerimedicin. Status og udvikling. Esbjerg: Sydjysk Universitetsforlag, 1988:123-41.

14 Bang J, Fisherman M, Franck C, Lyngenbo O, Nielsen A, Weihe $P$. Dödsulykker blant söens folk. In: Jepsen JR, Christensen JM, eds. Söfarts-og fiskerimedicin. Status og udvikling. Esbjerg: Sydjysk Universitetsforlag, 1988:143-70.

15 Vanggärd L, Nielsen S. Arbejdsmiljöet i dansk fiskeri. Ugeskr Laeger 1977;139:413-24.

16 Pedersen HP. Dödsfall blant fiskere, FTFI-raport nr. 662.4-5.1.

Accepted 13 January 1992 